\title{
Conception Of Innovated System For Waste Disposal
}

\author{
doc. Ing. Jan Spisak, PhD \\ Ing. Dusan Nascak, PhD \\ Ing. Daniela Cuchtova
}

Development And Realization Workplace Of Raw Materials Extracting And Treatment, Faculty Of Mining, Ecology, Process Control And Geotechnology

Technical University of Kosice

doi: 10.19044/esj.2016.v12n5p35 URL:http://dx.doi.org/10.19044/esj.2016.v12n5p35

\begin{abstract}
Every year wastes are becoming a bigger problem which every individual or government must take note and solve it on the fly. If certain energy standards are fulfilled, the waste recovery in incineration plants or similar technological devices is possible. This measure should lead to more efficient waste combustion and its energy recovery. In our conditions, this can be achieved so that the heat generated during combustion will be also used to generate electricity respectively thermal energy. For a more efficient and optimal waste treatment was proposed a three-stage combustion system concept.
\end{abstract}

Keywords: Waste, innovated system, disposal

\section{Introduction}

The main environmental problem of the society today is the accumulation of waste and climate change caused by global warming of the atmosphere. This so-called "greenhouse effect" is caused by greenhouse gases such as $\mathrm{CO}_{2}, \mathrm{~N}_{2} \mathrm{O}, \mathrm{SF}_{6}$ and $\mathrm{CH}_{4}$ in particular, which is in large quantities formed and released in a scrapheap during decomposition of organic matter from municipal and industrial waste. The source of high amounts of carbon dioxide $\mathrm{CO}_{2}$ is energy (thermal power plants, heating plants, household heating), metallurgical industry, transport, industrial activity, production of construction binders (cement and lime), ceramic and glass, metallurgy, steel production. To produce unwanted emissions of CO2 also helps cement industry in terms of $\mathrm{CO}_{2}$ emissions. The amount of $\mathrm{CO}_{2}$ from cement production represent about $7 \%$ of the total $\mathrm{CO}_{2}$ emissions, from iron and steel production is about $10 \%$ and heat and energy production contributes to overall emissions to $50 \%$. The current legislation sets very 
strict emission limits at the output from the combustion process in waste combustion. It is essential to observe these emission limits by use of the latest technology.

One option to solve global environmental social problems is the use of suitable wastes as alternative fuels and also alternative raw materials. As alternative fuels appropriate waste with a high energy content are used, that can replace natural non-renewable fossil fuels in the generation of the necessary thermal energy and also substitute produced amounts of $\mathrm{CO}_{2}$ from fossil fuels. Suitable are mainly waste containing biomass. Thermal treatment of waste and biomass is one way of obtaining energy in form as heat as well as electricity. Utilization of these commodities as fuel is considered more environmentally friendly and replaces the previously used fossil fuels. But their combustion produces hazardous materials and these must be removed from the flue gas. The quantity of toxic substances from the biomass is dependent on the composition and processing. As an alternative raw material waste produced in various industries is used. This is mainly slag, fly ash, iron additives etc.

\section{The current state of waste thermal treatment - incineration plants}

Incineration plants are devices for converting waste into energy. The purpose of technological devices of municipal waste incineration plant is thermal disposal (combustion) of municipal solid waste, which is not possible otherwise utilize, associated with waste energy recovery i.e. production of electricity and heat. Heat recovered from the combustion of waste is mostly used to produce steam, which can serve for self-consumption of technology. For electricity production is in the plant usually installed condensing steam turbine with a generator. Part of the produced electricity can be used for own consumption of incineration plant and residue is e.g. into the public grid.

In the interest of individual government to ensure the use of the resulting energy (i.e. waste-to-energy policy) is regulation of the waste market, aimed at ensuring that the actual waste combustion process will be innovated for better energy conversion to electricity and heat. By this process a waste combustion also becomes a way for waste recovery, which gets to a higher level in the hierarchy of waste management in the European directives on waste. The incinerator plants are mainly used for combustion of mixed municipal waste, but in special cases plants are also used for combustion of hazardous waste. The vast majority of waste from the combustion process is recycled and re-used as building industry or as a source of precious substances.

List of waste incineration and co-incineration plants regularly registers and publishes the Slovak Environmental Agency. In Slovakia two 
waste incinerator plants for municipal waste with a capacity exceeding $2 \mathrm{t} / \mathrm{h}$ are operated, in the concrete OLO, Inc. (Bratislava) and Kosit, Inc. (Kosice). The other two large incineration plants (capacity $>2 \mathrm{t} / \mathrm{h}$ ) are used for industrial waste. Their operators are Slovnaft, Inc. (Bratislava) and Duslo, Inc. (Sala). Other waste incineration plants have lower capacity $(<2 \mathrm{t} / \mathrm{h})$ and their operators are Chemko Light Stabilizers, Ltd. (Strazske), Fecupral, Ltd. (Prešov), A.S.A. Slovakia, Ltd. (Kysucke Nove Mesto) and Incineration plant OZO, Inc. (Liptovsky Mikulas). Special role have large co-incineration plants with a total capacity of combustion is not mentioned, because it is combustion of waste with other materials. Operators are Holcim Slovakia, Inc. (Rohoznik), Carmeuse Slovakia, Ltd. (Kosice - Saca), V.S.H., Inc. (Turna nad Bodvou), Cemmac, Inc. (Horne Srnie) and Povazska cementaren, Inc. (Ladce).

Operation of incineration plants is subject to strict regulation and control. The plant with the quality technology is in the combustion of hazardous waste also safer than a landfill. However, it is highly expensive. In Slovakia market we miss suitable incineration plants with efficient flue gas separators. Neither third of incineration plants meet the emission limits set by law on air protection against pollutants and subsequent government regulations. According to some estimates, more stringent European emission limits meet in Slovakia about ten percent of incineration plants.

In the past, the construction of waste incineration plants was planned more or less spontaneously. To this day, nobody consistently analyze their needs for individual enterprises or regions. In Slovakia, compared to other countries, waste combustion in the other so-called non-purpose facilities (such as cement plants, metallurgical operations, CHP and also partly glassworks) is underutilized. More precise analysis might show, which companies with established incineration plants can after their reconstruction and streamlining of operation provide services also to another clients. The government should, however, help with financially and also by creating the appropriate economic instruments.

\section{Technology in incineration plants}

Incineration plants are based on the combustion of municipal waste and consequently on the production of steam in order to produce electricity and optionally recycled metals. The most common type of utilized devices are grate boilers for waste combustion. In some plants, the waste is crushed (torn to pieces) and partly sorted. This serves to separate some of the material in the first process stage. Next, in the second step before entering the boiler and combustion, the fractionation of flammable components is carried out. The waste may be treated either directly in the combustion chamber, or can be first milled and crushed into smaller pieces for better 
manipulability. The waste is then laded by cranes onto a moving belt, which supplies raw materials to the combustion chamber in which is a movable grate. The waste is combusted at a relatively high temperature in the presence of oxygen, typically about $850-1000^{\circ} \mathrm{C}$. After combustion, the flue gas is passing through the exchanger to generate steam, and then flue gas is refined by system of air pollution control (APC - Air Pollution Control). Fly ash from the bottom of the boiler is falling down through the grate and passes through magnetic separator to capture ferrous materials.

Generated heat from the combustion of municipal waste is used to produce steam. Then the steam passes through a turbine generator to produce electricity which is fed into the electrical power network. In the process of combustion more pollutants are generated, which include the oxides of nitrogen and sulfur, microparticles of mercury and cadmium, dioxins and furans, polycyclic aromatic hydrocarbons, polychlorinated biphenyls, carbon oxides $\mathrm{CO}$ and $\mathrm{CO}_{2}$. Mentioned facts mean need for the installation of relatively complex environmental facilities and thus the need for workers with higher education. Environmental equipment represents capital-intensive part of the system.

\section{The conception of innovated system of waste thermal treatment:}

The above system of waste treatment must currently be greatly revamped and complemented by the amount of additional equipment to be able to meet European limits for the environment.

A possible alternative for waste treatment is replacement respectively completion of current technologies on the concept of new innovative thermal treatment method.

This conception uses a three-stage combustion system. The device (originally designed for the treatment of biomass) is able effective evaluate by the thermal method a number of waste forms (organic, in some cases partly organic) in compliance with required environmental criteria, but it also allows to obtain a useful process components (heat, gas).

\section{Description of the technology on the example of biomass treatment}

By combustion of biomass it releases large amounts of heat, which is a need to use most efficiently. In order to be able to use the biomass as a fully-fledged source of energy, it is necessary to use a highly efficient technology for its obtaining. Heat generation is carried out by direct or indirect combustion of biomass. For combustion a high temperature, an adequate amount of air and sufficient time to burn is necessary.

For the direct combustion of biomass are flammable components combusted directly or after modification. Indirect combustion of biomass consists of pyrolysis, gasification and subsequent combustion of the 
generated gas. The aim of indirect combustion is to increase the efficiency of thermal treatment of biomass. Energetic criterion of process optimality is the maximum biomass energy transformed into heat. Thermodynamic criterion is the maximum temperature of the flue gas. These criteria did not match with any fundamental way of conversion. The external connection of the existing basic form is not preferred, as it saves in the loss of heat, thus reducing the efficiency of the process. Therefore, most of real processes are carried out integrated in a single device as a combination of basic processes (singlestage and two-stage combustion) in various configurations.

Single-stage process of heat generation occurs to the direct combustion of biomass, as well as products of pyrolysis and gasification. The source of heat is the flue gas as product of combustion. The criterion of combustion is the maximum combustion temperature of the fresh flue gas. The two-stage system consists of a gasification process and subsequent combustion of the generated gas. In this process the combustion products on a higher temperature level, which increases the efficiency of the process of energy recovery are generated. Gasification calorific value depends mainly on the content of $\mathrm{CO}$ and $\mathrm{CO}_{2}$, which is the result of Boudouard reaction without oxygen.

Three-stage process compared with two-stage process is extended by pyrolysis, which takes place before the gasification process. Pyrolysis is a thermal process in which comminuted biomass is heated above the temperature, which exceeds the limit of the chemical stability of contained substances. This process occurs at temperatures in the range $300-2000^{\circ} \mathrm{C}$ and divided into three groups according to the temperature. It is a lowtemperature $\left(<500^{\circ} \mathrm{C}\right)$, medium temperature $\left(500-800^{\circ} \mathrm{C}\right)$ and high temperature $\left(>800^{\circ} \mathrm{C}\right)$ process. This process leads to the release of the volatile substances from solid waste, until all volatiles and the remaining material with a higher energy level escape. The pyrolysis of the material provides a number of solid products, namely residue of the pyrolysis, pyrolysis oil, water and gas. The entering organic waste at three-stage combustion is heated indirectly by the through wall outgoing gas or by flue gas. In comparison with the two-stage combustion, the generated gas has higher heating value and the combustion gas temperature is higher (Fig. 1). 


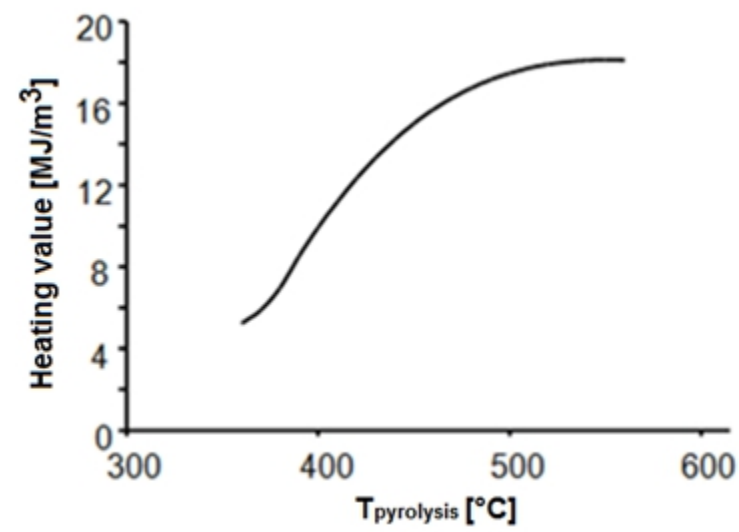

Fig. 1 Dependence of syngas heating value on pyrolysis temperature

Model prototype (Fig. 2) is composed of a gasification and combustion section. The pyrolysis and gasifying part are joined by flow of materials. The gases of these areas pass out into the combustion section. Pyrolysis process is carried out by heat transmitted from flue gas. Effective pyrolysis is a high temperature $\left(1200-1500^{\circ} \mathrm{C}\right)$. The high temperature ensures that all products of pyrolysis are in the gas phase and do not require any specific treatment. High temperature combustion devices are particularly suitable for the combustion of large sample, such as biomass, which during combustion releases a number of smokes.

In the gasification part of the unit are provided thermal and concentration conditions for the generation of synthesis gas. Increased amount of air causes the increase of the portion from gasification at the expense of pyrolysis. This reduces the thermodynamic efficiency of the process. Therefore parameters of the device need to be designed so that the pyrolysis recovery was close to the maximum value, which depends on the chemical composition of materials.

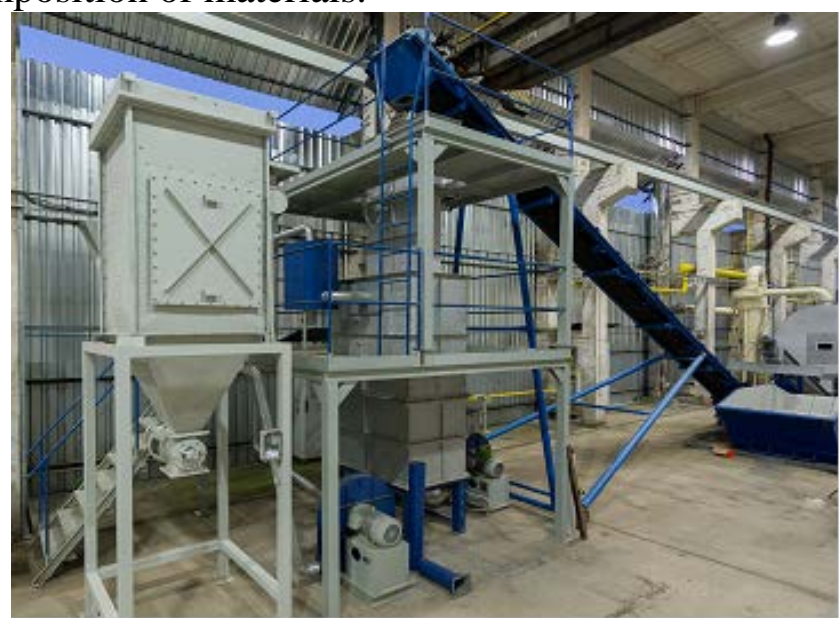

Fig. 2 Prototype of device for three-stage combustion process 


\section{Conclusion:}

The benefits of waste combustion are that significantly reduces the amount of solid waste going to landfill. Part of hazardous substances is removed during combustion. By combustion the heat, usable for heating or to generate electricity, is released. In contrast, the disadvantages are that in the case of incomplete cleaning of emerging combustion gases the hazardous gases are brought into air and cause air pollution.

Construction of quality, environmentally-sound incineration plant is very expensive and is often subsidized by state finance from citizen taxes. Therefore, as an effective alternative is designed and proven technology of three-stage combustion of waste and biomass. This technology can be used for combustion of certain types of waste, what can improve the environmental burden of individual regions by disposal of such waste types. By using high temperature combustion may be largely reduced respectively removed unwanted emissions from waste combustion process. For example, in the treatment of biomass respectively organic wastes generated gas may be used to produce heat or electric energy, residual ash for application in acidic soils, polluted by emissions from industrial areas.

\section{Acknowledgements}

This contribution/publication is the result of the project implementation Research excellence centre on earth sources, extraction and treatment supported by the Research \& Development Operational Programme funded by the ERDF. (ITMS: 26220120017)

\section{References:}

Mikula, J., Nascak, D., Kerekanic, J. (2014) Three-stage furnace for biomass thermal treatment, In: European Scientific Journal, Vol. 10, no. 18, p. 45-51, ISSN 1857-7881.

Frankovska, J. et al. (2010) Atlas of remediation methods for environmental weights, State Geological Institute of Dionyz Stur, Bratislava, ISBN 978-8089343-39-3.

Property \& Environment s. r. o.: Waste incineration plants. Available on the web: http://www.odpady-portal.sk/Dokument/100872/spalovneodpadov.aspx.

Zackova, K. Slovakia lacks the waste incineration plants, the existing plants are unused. Trend.sk, TREND Holding, Bratislava. Available on the web: http://www.etrend.sk/trend-archiv/rok-/cislo-September/na-slovenskuchybaju-spalovne-odpadu-jestvujuce-su-vsak-nevyuzite.html.

Spisak, J., Mikula, J., Glocek, J., Nascak, D. (2013) Thermal treatment of technogenic waste, In: Odpady, Vol. 13, no. 8, p. 7-11, ISSN 1335-7808. 